\title{
AN INVESTIGATION OF THE PROFESSIONAL COMMITMENT LEVELS OF OFFICER CLASS SEAFARERS OF GENERATION Y IN TERMS OF SEVERAL VARIABLES
}

\begin{abstract}
The employees' level of commitment to their profession has been on the decrease due to the challenging conditions of seafarers' profession. There exist many factors affecting professional commitment. Among the most prominent ones are age, hometown and personality characteristics. There are opinions in the literature that generation Y employees lack such emotions as commitment, sense of belonging and team spirit. Therefore, this research focused on seafarer who recently started the profession of seafarers as a member of generation $\mathrm{Y}$. The relationship between personality characteristics and professional commitment was measured through several variables. The professional commitment scale developed in health sector was applied to seafarers from generation $\mathrm{Y}$ who are employed in maritime sector after reliability and validity studies were performed. The relationship between personality characteristics and professional commitment was measured through several variables.
\end{abstract}

\section{Introduction}

In the literature of work psychology, three separate commitments are mentioned, which are job satisfaction, organizational commitment, and job commitment. There is confusion regarding job commitment and professional commitment. Professional commitment involves occupations that are formed as a result of education, specialization and career planning. For this reason, the professional commitment levels of the officer class, whom we may describe as white-collar seafarers, were examined in the study. In various research conducted in many sectors, it has been found that generation $\mathrm{Y}$ employees have low commitments and are difficult to be motivated (Rajput et al., 2012; Gürbüz, 2015). Seafarers are difficult and toilsome. Leaving the job in the early years of the profession is a frequently observed phenomenon. Managers of maritime companies state that with the arrival of generation $\mathrm{Y}$, leaving the profession has started to occur at much younger ages. The difficulty and toilsome characteristic of seafarers is a significant factor in this phenomenon. Studies regarding reducing ship accidents and human resources for quality ship management have increased at an institutional level. According to the research conducted on 150 accidents by the IMO sub-committee based on Flag State audits, $80 \%$ of accidents are caused by human error while only a few accidents resulted from technical problems (IMO, 2008). To prevent ship accidents and to eliminate human errors, it is necessary to manage seafarers appropriately and to ensure their commitment to the profession. Many factors affect professional commitment, the most important of which are personality characteristics, followed by age, demographic properties and social relations. There has recently been much emphasis on and complaint about the negative characteristics of generation $\mathrm{Y}$, especially about their low levels of commitment. Many research results also confirm their low level of organizational and professional commitment. Accordingly, the study aimed to examine the effect of personality characteristics of generation $\mathrm{Y}$ seafarers and other variables on professional commitment.

\section{The purpose of the research}

The question of generations, which has caused much debate in a number of fields and triggered research, draws the attention of academics and the business world as well. All research 
conducted on this issue has concluded that generation $\mathrm{Y}$ employees have low levels of motivation and workplace commitment. In addition to the high turnover rate of staff in the maritime sector, the rate of leaving the job is also high. Family-related and social issues and challenging conditions of the profession constitute the most significant causes of this situation. In the interviews conducted with maritime professionals, it has been revealed that leaving the job earlier compared to previous years and working on the land at maritime-related businesses occur in the early stages of the profession. In the study conducted by Kuran (2018) on generation $\mathrm{Y}$, it was found that generation $\mathrm{Y}$ set an international career goal before they start work life, and they set a private life balance after three years of experience (Kuran, 2018). It can be claimed that generation Y display intention to leave working at sea early since they attach importance to work-life balance. It is known that generation Y seafarers are in search of work on the land, career change and a second career due to work-life balance. As a result of the reasons mentioned, in the study, to measure the level of commitment of generation Y who just entered the occupation of seafarers to the profession, professional commitment scale for nurses developed by $\mathrm{Lu}$ et al. was revised and adapted in line with the professional views of experts working in management positions in institutional maritime companies in the maritime sector. Reliability and validity of the scale were ensured, and professional commitment levels of generation Y Turkish officer seafarers were measured together with the three sub-dimensions of showing effort, professional membership and target value.

\section{Theoretical Background: Generation Y and Their Characteristics}

In studies carried out on generations, it has been stated that each generation has its unique characteristics. The conflict between generations is an important issue faced in the business world.

These disparities are believed to cause tensions between generations several times. According to a survey conducted by the Human Resources Management Society (2004), 40 percent of human resource practitioners perceive workplace tension as a direct result of generational differences (Zopiatis et al., 2012).

In order to understand the conflict between generations in the business world, it is necessary to figure out the group of people who are named generation $\mathrm{Y}$ and who have quite different characteristics from other generations and thus are difficult to manage. In today's world, a significant portion of the labor force consists of generation Y members who were born between 1980-2000. Generation Y is a name attributed to individuals born between the years of 1980 and 2000. This generation is also called the Internet generation, echo-boomers, millennials, and nexters. Such definitions are used in order to emphasize the difference in generation $\mathrm{Y}$ from previous generations (Broadbidge et al., 2007: 523-544). Generation Y (1980-2003) is a technology-friendly generation and when compared to generation $\mathrm{X}$, they are individualistic and goal-oriented. The number of representatives of this generation is much higher in comparison to other countries (Çam, 2009).

The most negative characteristics attributed to this generation are little sense of belonging and low work motivation (Twenge, 2007; Lub et al., 2011). In their study conducted on 124 people working in the electric and electronic industry in Malaysia, Rajput et al. (2012) found that generation $\mathrm{Y}$ members are intrinsically and extrinsically less motivated and had less organizational commitment compared to generation $\mathrm{X}$ members. In another study, it was determined that generation $\mathrm{X}$ nurses had lower intentions to leave the profession and higher job 
satisfaction and professional commitment in comparison to generation $\mathrm{Y}$ nurses (Y1lmaz, Esencan and Özdil, 2017). In the study carried out by Gürbüz (2015) titled "Generational Differences: A Myth or A Fact?", an analysis was performed on a set of data on 731 employees employed in seven different work branches in Ankara, Turkey. As a result of the analysis, generation Y, which was the youngest generation in the sample group, was found to have the lowest level of commitment.

In studies conducted on generations, however, generation $\mathrm{Y}$ was especially claimed to be "the generation that received the best education" despite all their negative characteristics (Brown, 2009). In the study carried out by Evrim Kuran (2017), it was determined that generation Y members gave priority to work-life balance. Even though they get paid for it, extra working hours and additional tasks decrease their motivation and already low organizational commitment (Muslu, 2017). Although such reasons as being a profession with limited-time contract, not working at a fixed location, and opportunity to earn a lot of money motivate generation $\mathrm{Y}$ members to prefer the profession in the first place and work at sea, the fact that they do not like hierarchy and classical management style, that they do not see working as a goal, and that they demand the workplace to be an entertaining place may cause them to leave the profession in early years. Material rewards can be used to increase employees' motivation and commitment to the company; however, generation $\mathrm{Y}$ has different expectations such as personal development, opportunity to socialize, and autonomy as well (Özaydın, 2019). These expectations need to be considered by businesses through all processes of human resources management.

\section{Theoretical background: Professional Commitment}

Commitment is a significant portion of an employee's psychological conditions (Albdour and Altarawneh, 2014: 194). Commitment to the job indicates the strength of an individual's psychological identification with his/her job (Tinaz, 2017). One of the important commitments attitudes in work life is professional commitment. One of the constructs that are gaining importance in research carried out on types of commitment in work life is professional commitment (Goswani, Mathew and Chadha, 2007). Professional commitment is a remarkable element that has a bearing on the work-related emotions and attitudes of employees working at workplaces. The following definitions regarding professional commitment can be come across in the literature.

Morrow, in a similar vein, has defined professional commitment as the profession turning into an important element in an individual's life (Morrow, 1983: 489).

According to Lachman and Aranya, for the employees to perform their job better, they should spend effort and time to improve themselves technically. Therefore, professional commitment refers to committing oneself to his/her occupation and professional career, believing in professional ethics and goals, and adopting them (Lachman and Aranya, 1986; Aslan, 2008).

Professional commitment is a psychological bond that an individual develops between himself/herself and his/her occupation based on the emotional reaction towards an occupation (Meyer, Allen and Smith, 1993). It is "foregrounding professional identity, making efforts for the occupation owned, committing oneself to the occupation and commitment to ethical principles" (Sorensen and Sorensen, 1974; Lachman and Aranya, 1986). 
Professional commitment consists of three dimensions: the affective dimension, the normative dimension, and the continuance dimension (Meyer et al., 1993).

Different perspectives exist in defining professional commitment. Cohen (2003) states that there has been confusion as regards the meaning of the concept as concepts such as occupation, career, and profession are used interchangeably. For this reason, he offers to express all of them with one single term. The study we conducted was aimed at officer class seafarers. Labor, experience, examinations and training are required to become a seafarer in the officer class. Looking from this perspective, as opposed to Cohen's approach, we used the term "professional commitment" based on the explanations made by Meyer et al. (1993). Meyer stated that if there is a need to use a general term, it has to be the concept of "occupation" and that the concept of "profession" is separate.

At this point, it does not look reasonable to use the same concept for a job that is achieved through training, effort, and experience with high prestige in society and for a job that could be performed by anyone with a little training at the same time. Thus, since our study includes officer class, it would be more appropriate to use professional commitment rather than occupational commitment. Baysal defined professional commitment as to how central in his/her life an individual assesses his/her profession as a result of his/her efforts he/she has made to gain skills and expertise in a certain field (Baysal, 1999). One can assume that the level of commitment to a difficult job looking simple and which not everyone wants to do would below. In this sense, occupational commitment and professional commitment should be considered separately.

\section{Attitudes, emotions, and behaviors related to professional commitment}

Professional commitment affects many positive job attitudes and behaviors. The individual's emotions regarding the organization and profession could be more effective in his/her decisions about a profession. In this context, it can be argued that other types of commitments may have an effect on the formation of professional commitment (Blau and Lunz, 1998). At one end of the professionalization process is the job, while the profession is located on the other end. It has been stated that one of the eight criteria for a job to be defined as a profession is professional commitment (Çetinkaya et al., 2015). Commitment to one's profession or organization is an important psychological concept that can help to explain employees' work behaviors (Meyer \& Herscovitch, 2001). Many factors affecting the success of management in workplaces also have an impact on professional commitment attitude. Individuals act and are mostly oriented by professional expectations rather than organizational expectations (Cohen, 2000). Benligiray and Sönmez (2011) put forth that an increase in professional commitment will lead to job commitment. Bagraim (2003), who addressed commitment with a professional focus, described the concept as a psychological condition that shaped the relationship of the employee with his/her profession and emphasized that it had powerful effects on whether the individual will maintain his/her profession.

Although professional and organizational commitment seems to be separate concepts, many studies concluded that both commitment types are in interaction with each other in their effects on work behaviors such as job satisfaction and intention to leave (Lachman and Aranya, 1986; Tinaz, 2017). In their study, they conducted on academics, Dorenkamp and Weiß determined that one important factor in job satisfaction in the context of academics is professional commitment (Dorenkamp \& Weiß, 2018). It can be stated that employees whose job and 
organizational commitment levels are both high is are the group of employees with the highest motivation (Solmuş, 2004). The assumption that senior employees usually have higher levels of job commitment is supported by research findings (Tinaz, 2013).

Profession as a commitment goal can transcend engagement with the employing organization; that is, in comparison with organizational commitment, engagement with the profession has a distinct and potentially stronger impact on attitudes and behavior, especially in relation to professional activity (Becker et al., 2015; Hoff, 2000; Meyer, Allen, \& Smith, 1993). The organizational commitment of employees is just as important as their Professional commitment since it affects their motivation for work in a given profession (task) (Carson and Bedian, 1994). Job commitment is strongly related to motivation and job satisfaction (T1naz, 2013).

Unlike organizational commitment, professional commitment is related to the employee's understanding of the importance of his/her profession in his/her life as a result of the skills and expertise he/she acquires. In this sense, professional commitment can be defined as the employee's perception of the importance degree of his/her profession in his/her life after all the efforts he/she has made to gain skills and expertise in a certain field (Baysal and Paksoy, 1999:9). The definition of job commitment, on the other hand, may show similarity to the definition of professional commitment; however, when conditions of the workplace and the job are in question, its definition may vary. Çakır (2001) defined job commitment as an employee's degree of identifying, integrating and involving himself/herself with the job he/she has. Although many factors affect job commitment, it is a type of commitment that occurs as a result of the interaction between organizational commitment and professional commitment.

Besides, it has been argued that professionally committed individuals do more research to improve their profession and that they usually experience work-family conflicts (Balay, 2000). Tinaz (2013) stated that the effect of professional commitment on performance could not be identified. Personal and other organizational variables, especially work-life balance, can have an impact on performance.

Dorenkamp and Ruhle (2018), in a research paper on academic careers, noted that as normative professional commitment grows with socialization in the academic profession, the internalized normative pressure to pursue an academic career will lead to a strong association with the profession and positive feelings of being part of it. Individuals with high job commitment have higher job satisfaction and show more successful performance. As a result of high job commitment, intention to leave decreases, and the amount of working time increases (Tinaz, 2013).

When an individual spends years for his/her profession, and his/her profession gradually becomes important for him/her, he/she starts to internalize the values and ideology of his/her profession. The professional commitment that develops in this way is classified under three sub-dimensions (Morrow, 1983: 489):

1. The general attitude towards the profession: It involves value judgments related to the profession. In this case, the individual identifies work with life. For example, he/she develops discourses such as "one cannot get joy from life without satisfaction with his/her job or profession."

2. Professional planning thought: At this level, the individual makes investments related to his/her profession in the future. The individual develops long-term plans and ideas to improve 
himself/herself and advance in his/her career. According to Blau, such efforts of individuals can be measured through their utilization of various media bodies, professional and educational institutions and other opportunities and their participation in meetings associated with their profession (Blau, 1985: 278).

3. The relative importance of the profession: It is the revealing of the preferences between the profession and non-professional activities.

\section{The Research Method}

The study was conducted on seafarer who newly started the profession of the seafarer. The sample of the study included the graduates of Maritime programs of Ordu University, which admits students from all regions of Turkey, currently working in the maritime sector. There is no professional commitment scale applied in the maritime sector. For this reason, studies conducted in this field were surveyed. In the applied scales, professional commitment is shaped under four factors during the process of professional experiences and socialization, which are: (1) Eagerness to show effort, (2) Professional membership (maintaining and preserving), (3) believing in goals and values, and (4) a continuing chance of career. Researchers generally use only the first three factors (Lu, Chou and Chang, 2000; Lu, Lin, Wu, Hsieh and Chang, 2002; Teng, Shyu and Chang, 2007).

Similarly, the first three factors were used in the study. The Turkish version of the "Nursing Professional Commitment Scale," which was developed by Lu et al. and which was adopted to Turkish in 2015 by Aynur Çetinkaya et al. along with reliability and validity studies, was adapted to the maritime sector upon the opinions of experts. The reliability and validity of the scale were ensured by applying it to active seafarers working in the maritime sector. Finally, differences between groups were examined through several variables.

\section{Field Research and Data Collection Process}

The research was conducted on active seafarers from generation Y. To this end, as it has graduated from all regions of Turkey, Ordu University was chosen and newly graduated seafarers were accessed through the graduate information system. The scale was applied to 248 actively working seafarers. In this sense, the research was carried on a sample covering the whole of Turkey.

Internal consistency was evaluated using Cronbach's alpha. The minimum acceptable value for Cronbach's alpha was 0.70; the internal consistency of the range below this value was considered low. Alpha values between 0.80 and 0.90 were generally preferred.

According to the Table, the total variance explained by the three factors was $53 \%$. According to the principal components analysis, the variance explained by the first factor was $28 \%$, the second factor was $19 \%$, and the third factor was $6 \%$. The only problem was that the 25 th question was under the 0.3 -factor load. For this reason, the $25^{\text {th }}$ question was removed from the scale.

Confirmatory factor analysis was performed. In the confirmatory factor analysis, it was determined that there was only 1 -factor loading below 0.30 , where the fit indexes were acceptable. The exclusion of this item from the survey may be considered an option.We used correlation analysis to examine the interrelation of numerical data. In the table below, correlation coefficients and p-value of less than 0.05 and 0.01 were indicated. 
Correlation coefficients express the magnitude of the effect, while $p$ values test the presence of these observed effects. Generally accepted comments for effect sizes are as follows;

$0-0.199$ Very weak, $0.2-0.399$ Weak, $0.4-0.499$ Medium, $0.5-0.799$ Strong, $0.8-1$ Very Strong. Descriptive dimensions and professional commitment dimensions differed according to demographic data.

\section{Profile Variables Section:}

Seven different profile variables for generation Y seafarers.

1. Planned years for working at sea, 2. Place of birth (region), 3. Type of ship employed at 4. High school graduated from, 5. Reason for preferring to be seafarers, 6. Department graduated from, 7. Gender

Table 1. Descriptive Statistics

\begin{tabular}{|l|l|c|l|l|c|}
\hline Parameter & Value & $\mathrm{n}(\%)$ & Parameter & Value & $\mathrm{n}(\%)$ \\
\hline Planned years & More than 10years & $80(32.3 \%)$ & High school graduated & Private High Sch. & $88(35.5 \%)$ \\
\hline & $1-2$ years & $19(7.7 \%)$ & & Military H.S. & $34(13.7 \%)$ \\
\hline & 2-5 years & $33(13.3 \%)$ & & General H.S. & $15(6.0 \%)$ \\
\hline & 5-7 years & $40(16.1 \%)$ & & Religious H.S. & $9(3.6 \%)$ \\
\hline & 7-10 years & $59(23.8 \%)$ & & Vocational H.S. & $93(37.5 \%)$ \\
\hline & Mediterranean & $41(16.5 \%)$ & Reason for preference & Friends & $65(26.2 \%)$ \\
\hline & Others & $53(21.4 \%)$ & & Parents & $84(33.9 \%)$ \\
\hline & Aegean & $40(16.1 \%)$ & & Teacher & $16(6.5 \%)$ \\
\hline & Black Sea & $53(21.4 \%)$ & & Social Media & $32(12.9 \%)$ \\
\hline & Marmara & $55(22.2 \%)$ & & TV & $16(6.5 \%)$ \\
\hline & Chemical Tanker & $45(18.1 \%)$ & Department graduated & Deck & $105(42.3 \%$ \\
\hline & Container & $14(5.6 \%)$ & & Naval Architect & $16(6.5 \%)$ \\
\hline & General Cargo & $65(26.2 \%)$ & & Maritime Engine & $104(41.9 \%$ \\
\hline & Oil Tanker & $56(22.6 \%)$ & Gender & Male & $182(73.4 \%$ \\
\hline & Roro \& Passenger & $9(3.6 \%)$ & & Female & $58(23.4 \%)$ \\
\hline
\end{tabular}

\section{Reliability Analysis}

Internal consistency was evaluated using Cronbach's alpha. The minimum acceptable value for Cronbach's alpha was 0.70 ; the internal consistency of the range below this value is considered low. Alpha values between 0.80 and 0.90 are generally preferred.

In Table 2, the mean Cronbach's Alpha coefficient for the sub-dimension of Showing Effort is 0.9, which indicates that it is reliable. Table 3 shows that the mean Cronbach's Alpha coefficient for the sub-dimension of Professional Membership is reliable at the value of 0.91. The mean Cronbach's Alpha coefficient for the sub-dimension of Goals and Values was found to be 0.69 , as presented in Table 4. 
Table 2. Reliability table for showing effort

\begin{tabular}{|c|c|c|c|}
\hline Dimension & Cronbach's Alpha & Mean \pm SD & Median (Min-Max) \\
\hline Total & 0.9 & & \\
\hline D1 & 0.89 & $4.29 \pm 0.97$ & $5.0(1.0-5.0)$ \\
\hline D2 & 0.89 & $4.29 \pm 0.9$ & $4.0(1.0-5.0)$ \\
\hline D3 & 0.89 & $4.05 \pm 1.01$ & $4.0(1.0-5.0)$ \\
\hline D4 & 0.89 & $3.85 \pm 1.1$ & $4.0(1.0-5.0)$ \\
\hline D5 & 0.89 & $3.71 \pm 1.15$ & $4.0(1.0-5.0)$ \\
\hline D6 & 0.89 & $4.17 \pm 1.01$ & $4.0(1.0-5.0)$ \\
\hline D7 & 0.89 & $3.98 \pm 1.01$ & $4.0(1.0-5.0)$ \\
\hline D8 & 0.89 & $3.7 \pm 1.1$ & $4.0(1.0-5.0)$ \\
\hline D9 & 0.91 & $3.22 \pm 1.29$ & $3.0(1.0-5.0)$ \\
\hline D10 & 0.89 & $4.22 \pm 1.01$ & $4.0(1.0-5.0)$ \\
\hline D11 & 0.89 & $3.99 \pm 1.03$ & $4.0(1.0-5.0)$ \\
\hline D12 & 0.91 & $3.81 \pm 1.13$ & $4.0(1.0-5.0)$ \\
\hline D13 & 0.9 & $4.02 \pm 1.17$ & $4.0(1.0-5.0)$ \\
\hline
\end{tabular}

Table 3. Professional Membership

\begin{tabular}{|c|c|c|c|}
\hline Dimension & Cronbach's Alpha & Mean \pm SD & Median (Min-Max) \\
\hline Total & 0.91 & & \\
\hline D14 & 0.92 & $3.33 \pm 1.41$ & $3.0(1.0-5.0)$ \\
\hline D15 & 0.91 & $3.92 \pm 1.35$ & $4.0(1.0-5.0)$ \\
\hline D16 & 0.9 & $4.29 \pm 1.15$ & $5.0(1.0-5.0)$ \\
\hline D17 & 0.89 & $3.96 \pm 1.25$ & $4.0(1.0-5.0)$ \\
\hline D18 & 0.89 & $4.02 \pm 1.26$ & $5.0(1.0-5.0)$ \\
\hline D19 & 0.89 & $4.12 \pm 1.17$ & $5.0(1.0-5.0)$ \\
\hline D20 & 0.9 & $3.83 \pm 1.33$ & $4.0(1.0-5.0)$ \\
\hline D21 & 0.91 & $3.76 \pm 1.33$ & $4.0(1.0-5.0)$ \\
\hline
\end{tabular}

Table 4. Goals and values

\begin{tabular}{|c|c|c|c|}
\hline Dimension & Cronbach's Alpha & Mean \pm SD & Median (Min-Max) \\
\hline Total & 0.69 & & \\
\hline B22 & 0.66 & $3.56 \pm 1.08$ & $4.0(1.0-5.0)$ \\
\hline B23 & 0.56 & $4.23 \pm 1.0$ & $5.0(1.0-5.0)$ \\
\hline B24 & 0.57 & $3.95 \pm 1.07$ & $4.0(1.0-5.0)$ \\
\hline B25 & 0.79 & $3.15 \pm 1.21$ & $3.0(1.0-5.0)$ \\
\hline B26 & 0.58 & $3.95 \pm 1.07$ & $4.0(1.0-5.0)$ \\
\hline
\end{tabular}




\section{Exploratory Factor Analysis}

\section{Table 5. Exploratory Factor Analysis}

\begin{tabular}{|l|c|c|c|}
\hline & Factor 1 & Factor 2 & Factor 3 \\
\hline Question 1 & 0.78 & & \\
\hline Question 2 & 0.77 & & \\
\hline Question 3 & 0.67 & & \\
\hline Question 4 & 0.78 & & \\
\hline Question 5 & 0.71 & & \\
\hline Question 6 & 0.78 & & \\
\hline Question 7 & 0.67 & & \\
\hline Question 8 & 0.72 & & \\
\hline Question 9 & 0.55 & & \\
\hline Question 10 & 0.74 & & \\
\hline Question 11 & 0.64 & & \\
\hline Question 12 & 0.34 & & \\
\hline Question 13 & 0.39 & & \\
\hline Question 14 & & 0.47 & \\
\hline Question 15 & & 0.62 & \\
\hline Question 16 & & 0.84 & \\
\hline Question 17 & & 0.83 & \\
\hline Question 18 & & 0.87 & \\
\hline Question 19 & & 0.89 & \\
\hline Question 20 & & 0.75 & \\
\hline Question 21 & & 0.72 & \\
\hline Question 22 & & & 0.46 \\
\hline Question 23 & & & 0.33 \\
\hline Question 24 & & & 0.36 \\
\hline Question 25 & & & $\mathbf{0 . 1 0}$ \\
\hline Question 26 & & & 0.31 \\
\hline Variance Explained & 0.28 & 0.19 & 0.06 \\
\hline
\end{tabular}

According to Table 5, the total variance explained by three factors is 53\%. According to the principal components analysis, the variance explained by the first, second, and third factor was $28 \%, 19 \%$, and $6 \%$, respectively. The only problem was that the 25 th question was under factor load 0.3 . 
Table 6. Confirmatory Factor Analysis

\begin{tabular}{|l|l|c|c|c|c|}
\hline \multicolumn{7}{|c|}{} \\
\hline & & Estimate & Std. Error & z-value & P-value \\
\hline Showing Effort = & D1 & 1 & & & \\
\hline & D2 & 0.927 & 0.061 & 15.088 & $<0.001$ \\
\hline & D3 & 0.845 & 0.077 & 11.027 & $<0.001$ \\
\hline & D4 & 1.001 & 0.08 & 12.517 & $<0.001$ \\
\hline & D5 & 0.94 & 0.086 & 10.981 & $<0.001$ \\
\hline & D6 & 0.998 & 0.073 & 13.701 & $<0.001$ \\
\hline & D7 & 0.882 & 0.075 & 11.841 & $<0.001$ \\
\hline & D8 & 0.858 & 0.082 & 10.457 & $<0.001$ \\
\hline & D9 & 0.62 & 0.105 & 5.89 & $<0.001$ \\
\hline & D10 & 0.952 & 0.072 & 13.167 & $<0.001$ \\
\hline & D11 & 0.895 & 0.079 & 11.334 & $<0.001$ \\
\hline & D12 & 0.355 & 0.097 & 3.66 & $<0.001$ \\
\hline & D13 & 0.684 & 0.097 & 7.067 & $<0.001$ \\
\hline Professional Membership $=\sim$ & D14 & 1 & & & \\
\hline & D15 & 1.185 & 0.177 & 6.683 & $<0.001$ \\
\hline & D16 & 1.327 & 0.173 & 7.671 & $<0.001$ \\
\hline & D17 & 1.58 & 0.198 & 7.983 & $<0.001$ \\
\hline & D18 & 1.562 & 0.196 & 7.953 & $<0.001$ \\
\hline & D19 & 1.458 & 0.182 & 8.014 & $<0.001$ \\
\hline & D20 & 1.386 & 0.191 & 7.251 & $<0.001$ \\
\hline & D21 & 1.164 & 0.177 & 6.593 & $<0.001$ \\
\hline & D22 & 1 & & & \\
\hline & D23 & 1.594 & 0.222 & 7.182 & $<0.001$ \\
\hline & D24 & 1.417 & 0.216 & 6.563 & $<0.001$ \\
\hline & D25 & 0.252 & 0.17 & 1.49 & 0.136 \\
\hline & D26 & 1.381 & 0.21 & 6.587 & $<0.001$ \\
\hline
\end{tabular}

Considering the results of the confirmatory factor analysis, Question 25 was removed from the scale. According to model fit indexes, the results are acceptable.

Table 7. Model Fit Indexes

\begin{tabular}{|l|c|c|}
\hline Model Fit Indexes & Model & Acceptable \\
\hline X2/sd & 2.7 & $0<\mathrm{X} 2 / \mathrm{sd}<5$ \\
\hline CFI & 0.84 & $0,90 \leq \mathrm{CFI} \leq 1,0$ \\
\hline RMSEA & 0.09 & $0,00 \leq \mathrm{RMSEA} \leq 0,10$ \\
\hline AIC & $13875<14920$ & AIC model $<$ AIC independent models \\
\hline BIC & $13884<14929$ & BIC model $<$ BIC independent models \\
\hline
\end{tabular}

In the confirmatory factor analysis, it was determined that there was only 1-factor loading below 0.30 , where the fit indexes were acceptable. The exclusion of this item from the survey may be considered an option. 


\section{Evaluation of correlations between the sub-dimensions of professional commitment}

Table 8.

\begin{tabular}{|l|c|c|c|c|c|}
\hline & 1 & 2 & 3 & Total & \\
\hline Showing Effort & $-0.44^{* *}$ & 1 & & & \\
\hline Goals / Values & $-0.32^{* *}$ & $0.53^{* *}$ & 0.1 & 1 & \\
\hline Profess. Memb. & $-0.34 * *$ & $0.46^{* *}$ & 1 & & \\
\hline Total & $-0.49^{* *}$ & $0.85^{* *}$ & $0.76^{* *}$ & $0.54^{* *}$ & 1 \\
\hline
\end{tabular}

Note: $* *$ p-value $<0.01$

Correlation coefficients express the magnitude of the effect, while p values test the presence of these observed effects. Generally accepted comments for effect sizes are as follows:

0 - 0.199 Very weak, $0.2-0.399$ Weak, $0.4-0.499$ Medium, $0.5-0.799$ Strong, 0.8 - 1 Very Strong

Table 9. Difference tests between the sub-dimensions of professional commitment according to the high schools the seafarers graduated from.

\begin{tabular}{|l|c|c|c|c|c|c|}
\hline & \multicolumn{5}{|c|}{ Mean \pm SD } & \\
\hline & \multicolumn{5}{|c|}{ Median (Min-Max) } & Vocational \\
\hline \multicolumn{1}{|c|}{ School } & Anatolian & Military H.S. & General H.S. & Religious H.S. & p \\
\hline $\begin{array}{l}\text { Showing } \\
\text { Effort }\end{array}$ & $54.13 \pm 7.66$ & $52.13 \pm 7.37$ & $49.93 \pm 8.82$ & $48.11 \pm 20.15$ & $49.05 \pm 10.04$ & $0.002(\mathrm{k})$ \\
\hline & $56(21-65)$ & $52(39-65)$ & $52(28-60)$ & $58(13-62)$ & $51(13-65)$ & \\
\hline $\begin{array}{l}\text { Profess. } \\
\text { Memb }\end{array}$ & $33.87 \pm 6.97$ & $29.75 \pm 7.85$ & $30.6 \pm 6.7$ & $29.56 \pm 11.56$ & $29.69 \pm 8.17$ & $0.001(\mathrm{k})$ \\
\hline & $36(11-40)$ & $32(8-40)$ & $31(10-40)$ & $31(10-40)$ & $31(8-40)$ & \\
\hline Goals/Values & $19.51 \pm 2.86$ & $18.72 \pm 3.72$ & $18.67 \pm 3.87$ & $16.0 \pm 8.54$ & $18.49 \pm 3.44$ & $0.318(\mathrm{k})$ \\
\hline & $20(7-25)$ & $19(5-25)$ & $18(11-25)$ & $20(5-25)$ & $19(5-25)$ & \\
\hline Total & $108.04 \pm 13.86$ & $99.14 \pm 12.14$ & $100.0 \pm 14.52$ & $93.67 \pm 22.86$ & $97.68 \pm 16.75$ & $<0.001(\mathrm{k})$ \\
\hline & $112(40-125)$ & $98.5(78-124)$ & $102.5(70-$ & $98(58-125)$ & $99(36-125)$ & \\
\hline
\end{tabular}

(k) Kruskal Wallis Test

According to Table 9, the participants' levels of professional commitment differ significantly in terms of high schools they have graduated from. To determine the difference between the groups, the Mann-Whitney test was employed. As a result of the analysis, it was found that Anatolian high school graduates had more professional commitment in comparison to vocational high school graduates in the sub-dimension of showing effort. In other words, Anatolian high school graduates make more effort.

In the professional membership sub-dimension, there is a significant difference between Anatolian high school graduates and military high school graduates. Anatolian high school graduates had higher levels of professional membership compared to military high school graduates.

Again in professional membership sub-dimension, there is a significant difference between Anatolian high school graduates and vocational high school graduates. In comparison to vocational high school graduates, Anatolian high school graduates have higher levels of Professional membership regarding seafarers.

In all the statements related to professional commitment, there are significant differences between Anatolian high school graduates, military high school graduates, and vocational high school graduates 
in favor of Anatolian high school graduates. Anatolian high school graduates have higher levels of professional commitment compared to the graduates of military and vocational high schools.

Table 10. Difference tests between the sub-dimensions of Professional commitment in terms of gender

\begin{tabular}{|c|c|c|c|}
\hline & \multicolumn{2}{|c|}{ Mean \pm SD } & \\
\hline & \multicolumn{2}{|c|}{ Median (Min-Max) } & \\
\hline Gender & Male (182) & Female (58) & p-value \\
\hline Showing Effort & $51.15 \pm 9.82$ & $53.06 \pm 6.96$ & $0.66(\mathrm{k})$ \\
\hline & $54(13-65)$ & $53(39-65)$ & \\
\hline Profess. Memb. & $31.45 \pm 7.98$ & $31.34 \pm 7.68$ & $0.894(\mathrm{k})$ \\
\hline & $32.5(8-40)$ & $32.5(8-40)$ & \\
\hline Goals/Values & $18.73 \pm 3.58$ & $19.15 \pm 3.48$ & $0.559(\mathrm{k})$ \\
\hline & $19(5-25)$ & $19(5-25)$ & \\
\hline Total & $101.84 \pm 16.65$ & $102.98 \pm 11.97$ & $0.751(\mathrm{k})$ \\
\hline & $106(36-125)$ & $102(78-125)$ & \\
\hline
\end{tabular}

(k) Kruskal Wallis Test

According to Table 10, no significant difference was identified in terms of seafarers' statements according to gender.

Table 11. Difference tests between the sub-dimensions of Professional commitment in terms of birth regions

\begin{tabular}{|c|c|c|c|c|c|c|}
\hline & \multicolumn{5}{|c|}{ Mean \pm SD } & \\
\hline & \multicolumn{5}{|c|}{ Median (Min-Max) } & \\
\hline Birth Region & Mediterr. (41) & Other (53) & Aegean (40) & Black Sea(53) & Marmara (55) & p-value \\
\hline Showing Effort & $53.42 \pm 8.18$ & $50.24 \pm 11.2$ & $52.08 \pm 7.59$ & $50.59 \pm 7.1$ & $51.58 \pm 11.69$ & $0.278(\mathrm{k})$ \\
\hline & $54.5(28-65)$ & $53(13-65)$ & $53(26-65)$ & $52(35-65)$ & $55.5(13-65)$ & \\
\hline Profess. Memb. & $31.73 \pm 7.44$ & $30.28 \pm 8.17$ & $32.95 \pm 7.0$ & $30.83 \pm 7.64$ & $32.33 \pm 8.64$ & $0.262(\mathrm{k})$ \\
\hline & $32(11-40)$ & $32(8-40)$ & $34(8-40)$ & $31.5(10-40)$ & $36(9-40)$ & \\
\hline Goals /Values & $19.28 \pm 2.93$ & $18.41 \pm 4.11$ & $19.71 \pm 2.72$ & $18.24 \pm 3.63$ & $18.62 \pm 4.24$ & $0.36(\mathrm{k})$ \\
\hline & $19(15-25)$ & $20(5-25)$ & $20(14-25)$ & $18(5-24)$ & $19(5-25)$ & \\
\hline Total & $104.79 \pm 13.05$ & $98.93 \pm 18.21$ & $104.85 \pm 12.17$ & $99.14 \pm 13.98$ & $104.0 \pm 18.74$ & $0.119(\mathrm{k})$ \\
\hline & $108(72-125)$ & $101.5(36-123)$ & $108(76-122)$ & $98.5(72-123)$ & $108(40-125)$ & \\
\hline
\end{tabular}

(k) Kruskal Wallis Test

According to Table 11, no significant difference was observed in terms of the statements of seafarers according to their birth regions.

Table 12. Difference tests between the sub-dimensions of Professional commitment in terms of departments

\begin{tabular}{|c|c|c|c|c|}
\hline & \multicolumn{3}{|c|}{ Mean \pm SD } & \\
\hline & \multicolumn{3}{|c|}{ Median (Min-Max) } & \\
\hline Department & Deck (105) & Naval Architecture. (16) & Maritime Engineering (104) & p-value \\
\hline Showing Effort & $52.86 \pm 8.55$ & $52.57 \pm 7.76$ & $50.79 \pm 10.15$ & $0.281(\mathrm{k})$ \\
\hline & $55(13-65)$ & $51(39-65)$ & $52(13-65)$ & \\
\hline Profess. Memb. & $33.9 \pm 6.25$ & $31.4 \pm 8.16$ & $28.84 \pm 9.02$ & $<0.001(\mathrm{k})$ \\
\hline & $36(12-40)$ & $33(16-40)$ & $31(8-40)$ & \\
\hline Goals /Values & $18.95 \pm 3.02$ & $17.21 \pm 4.41$ & $19.29 \pm 3.68$ & $0.224(\mathrm{k})$ \\
\hline & $20(5-24)$ & $18(5-22)$ & $20(5-25)$ & \\
\hline Seafarers Total & $105.82 \pm 15.41$ & $98.58 \pm 13.07$ & $99.3 \pm 15.95$ & $0.002(\mathrm{k})$ \\
\hline & $111(40-125)$ & $101(78-123)$ & $99(36-125)$ & \\
\hline
\end{tabular}

(k) Kruskal Wallis Test 
According to Table 12, it is seen that the participants' levels of professional commitment differ significantly in terms of the departments they have graduated from. To determine the difference between the groups, the Mann-Whitney U test was utilized. As a result of the analysis, it was found that in the seafarers' professional membership sub-dimension, the graduates of Marine Transportation and Management Engineering had a higher professional commitment in comparison to the graduates of the Maritime Engineering Department. In other words, the graduates of the deck department felt a higher level of professional membership.

In all the statements regarding professional commitment, graduates had higher scores when compared to the graduates of Naval Architecture and Marine Engineering departments. The professional commitment levels of deck department graduates were higher than those of the graduates of Naval Architecture and Marine Engineering departments.

Table 13. Difference tests between the sub-dimensions of professional commitment in terms of the planned period of working at sea

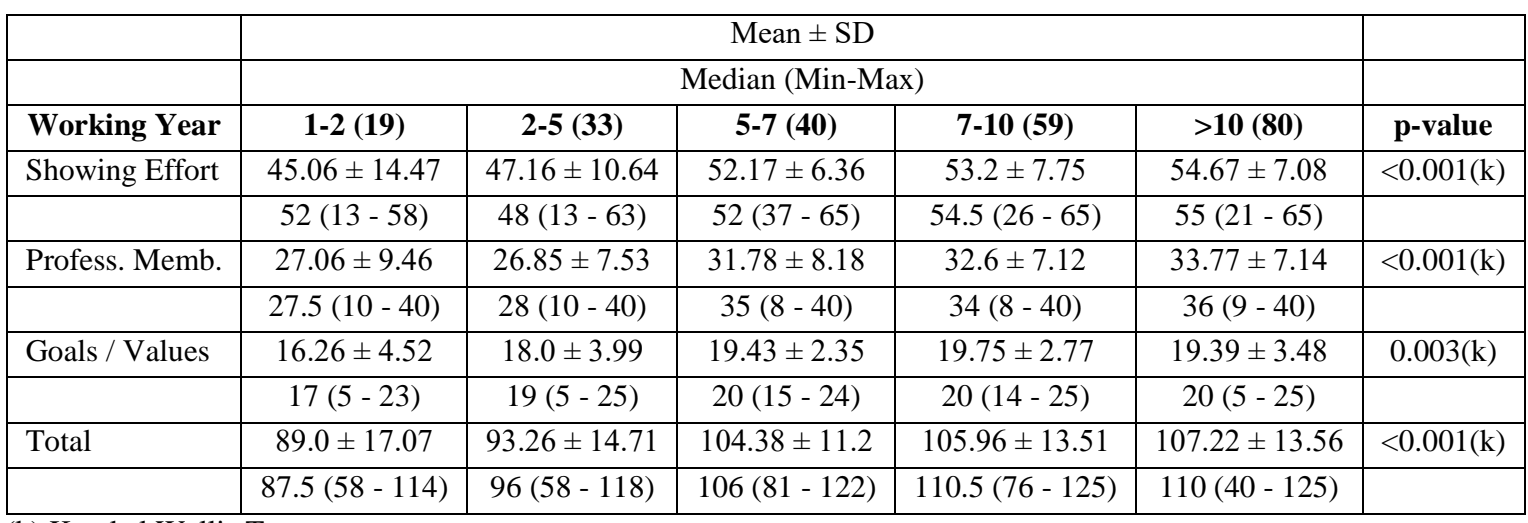

(k) Kruskal Wallis Test

According to Table 13, the participants' levels of professional commitment differ significantly in terms of the number of years they are planning to work. To identify the difference between the groups, the Mann-Whitney U test was used. As a result of the analysis, the participants' levels of professional commitment in the sub-dimension of showing effort were found to be higher in the 1-2 years of the working period compared to the period of 2-5 years. Furthermore, the seafarers who were planning to work 7-10 years were observed to have higher professional commitment in the sub-dimension of showing effort compared to those planning to work less than that period.

Regarding the professional membership sub-dimension, there was a significant difference between the seafarers who were planning to work more than 10 years and those planning to work 1-2 and 2-5 years. Besides, Significant differences were identified between those planning to work 5-7 years and 2-5 years as well as those planning to work 7-10 years and 2-5 years.

In relation to the sub-dimension of goals/values, significant differences were found between the seafarers planning to work 1-2 years and those planning to work more than 10 years in addition to the differences between 1-2 year group, and 1-2 year group and 5-7 and 7-10 year group.

In all the dimensions of professional commitment, significant differences existed between the seafarers planning to work more than 10 years and those planning to work 1-2 and 2-5 years. In the same vein, the differences between those planning to work 5-7 years and 1-2 year group, 2-7 year and 5-7 years group, 7-10 year and 1-2 year group, 7-10 year and 2-5 year group were found to be significant.

Briefly, the professional commitment of those who plan to work at sea more is different from that of the seafarers planning to work less. 
Table 14. Difference tests between the sub-dimensions of professional commitment in terms of the type of ship the participants work at

\begin{tabular}{|l|c|c|c|c|c|c|}
\hline & \multicolumn{5}{|c|}{ Median (Min-Max) } & Or SD \\
\hline \multicolumn{1}{|c|}{ Ship Type } & Chem.Tnk & Container (14) & Dry Cargo (65) & Oil Tnk. (56) & Roro/Pass. (9) & p-value \\
\hline $\begin{array}{l}\text { Showing } \\
\text { Effort }\end{array}$ & $51.0 \pm 7.46$ & $47.25 \pm 12.82$ & $49.93 \pm 10.67$ & $53.23 \pm 9.12$ & $53.33 \pm 7.07$ & $0.137(\mathrm{k})$ \\
\hline & $52(26-65)$ & $50(13-58)$ & $51.5(13-65)$ & $55(21-65)$ & $56(35-58)$ & \\
\hline $\begin{array}{l}\text { Profess. } \\
\text { Memb. }\end{array}$ & $29.74 \pm 7.6$ & $32.57 \pm 6.78$ & $30.92 \pm 8.72$ & $31.07 \pm 8.29$ & $28.78 \pm 8.87$ & $0.601(\mathrm{k})$ \\
\hline & $31(8-40)$ & $33(15-40)$ & $33.5(8-40)$ & $32(10-40)$ & $32(16-38)$ & \\
\hline Goals/Values & $19.09 \pm 3.8$ & $19.29 \pm 4.98$ & $18.54 \pm 3.92$ & $19.16 \pm 3.04$ & $19.22 \pm 2.73$ & $0.827(\mathrm{k})$ \\
\hline & $19(5-25)$ & $20(5-25)$ & $19(5-25)$ & $20(7-24)$ & $20(13-23)$ & \\
\hline Total & $99.83 \pm 11.74$ & $101.0 \pm 17.46$ & $99.67 \pm 16.69$ & $104.43 \pm 16.47$ & $101.33 \pm 13.8$ & $0.237(\mathrm{k})$ \\
\hline & $100(76-121)$ & $106.5(58-118)$ & $101(58-125)$ & $110(40-125)$ & $107(72-115)$ & \\
\hline
\end{tabular}

(k) Kruskal Wallis Test

According to Table 14, no significant differences were found in the statements of the seafarers in terms of the type of ship they work at.

Table 15. Difference tests between the sub-dimensions of Professional commitment in terms of the reason for preferring the profession

\begin{tabular}{|c|c|c|c|c|c|c|}
\hline & \multicolumn{5}{|c|}{ Mean \pm SD } & \\
\hline & \multicolumn{5}{|c|}{ Median (Min-Max) } & \\
\hline Reason for Pref. & Peer (65) & Parents (84) & Teacher (16) & Social Media (32) & TV (16) & p-value \\
\hline \multirow[t]{2}{*}{ Showing Effort } & $51.79 \pm 8.64$ & $52.02 \pm 10.49$ & $51.8 \pm 8.79$ & $51.19 \pm 6.62$ & $48.73 \pm 10.22$ & $0.414(\mathrm{k})$ \\
\hline & $53(26-65)$ & $54.5(13-65)$ & $53(33-65)$ & $50(39-63)$ & $53(21-60)$ & \\
\hline \multirow[t]{2}{*}{ Profess. Memb. } & $29.44 \pm 8.53$ & $31.83 \pm 8.33$ & $33.53 \pm 7.25$ & $33.13 \pm 5.5$ & $31.19 \pm 7.45$ & $0.14(\mathrm{k})$ \\
\hline & $31(8-40)$ & $35(9-40)$ & $36(18-40)$ & $33(22-40)$ & $31(12-40)$ & \\
\hline \multirow[t]{2}{*}{ Goals / Values } & $19.34 \pm 3.87$ & $18.71 \pm 3.84$ & $19.13 \pm 2.07$ & $19.32 \pm 2.27$ & $16.81 \pm 4.98$ & $0.352(\mathrm{k})$ \\
\hline & $20(5-25)$ & $19(5-25)$ & $19(16-23)$ & $20(14-22)$ & $18(5-23)$ & \\
\hline \multirow[t]{2}{*}{ Total } & $101.55 \pm 12.9$ & $102.79 \pm 16.61$ & $104.92 \pm 14.91$ & $103.41 \pm 12.18$ & $95.73 \pm 19.48$ & $0.43(\mathrm{k})$ \\
\hline & $101(72-125)$ & $108(58-124)$ & $108(70-125)$ & $104(78-124)$ & $98(40-115)$ & \\
\hline
\end{tabular}

According to Table 15, no significant difference was identified in the statements of the seafarers in terms of their reasons for preferring the profession.

\section{Conclusion and Recommendations}

In the studies conducted on professional commitment in the literature, it has been stated that a lack of professional commitment in employees has negative effects on work life. No research is carried out on professional commitment in the maritime sector in the literature. Particularly, individuals from Generation Y, who are known to have low levels of job commitment, started to work in the maritime sector as in other sectors. Therefore, the generation Y workforce constituted the sample of the study. The scale developed to measure professional commitment levels of new graduates in the health sector was used in the study. Developed by Lue et al., the scale which consisted of three sub-dimensions of Showing Effort, Professional Membership and Goals / Values and measured the level of professional commitment which develops as a result of education, effort and experience were applied to generation $\mathrm{Y}$ employees in the maritime sector. Cronbach's Alpha values total factor loads were found to be 0.90 for the sub-dimension of Showing Effort, 0.91 for Professional Membership and 0.69 for Goals / Values. 
Cronbach's Alpha values show that the scale is reliable. As a result of the reliability, validity and exploratory factor analysis, Question 25 was removed from the scale because it had load factors below 0.10 in the reliability analysis and 0.30 in confirmatory factor analysis. Following the reliability and validity analyses, the scale was tested with the Kruskal Wallis Test in terms of profile variables. According to the results of this test, significant differences were determined in the dimension of total professional commitment and all sub-dimensions in terms of high schools and departments the participants graduated from and planned years of working at sea. It was found that Anatolian high school graduates had more professional commitment compared to the graduates of other types of high schools. It was also determined that the graduates of Maritime Transportation Management Engineering (Deck Department) had higher levels of professional commitment compared to the graduates of other departments. One reason for the high level of professional commitment of the graduates of this department could be that graduates of other departments have lower levels of professional commitment resulting from the fact that they can find employment on the land and career opportunities in other sectors. And, the high level of professional commitment of deck department graduates can be explained by the fact that these graduates have the chance to be the captain of the ship at later stages of their careers and that being a captain is prestigious in the society. The shipmasters are the absolute authorities on the ships, which makes it all the more prestigious to study in deck department. No significant differences were found in the profile variables of gender, place of birth, type of ship they work on, and reasons for choosing the profession. Professional commitment has positive effects on many work-related attitudes and behaviors. For this reason, it is highly crucial for the management of ships. In recent years, managing the ships safely and preventing ship accidents have been on the agenda of the professionals of the maritime sector. In the research conducted by IMO, it was found that $80 \%$ of ship accidents are due to human error. Despite technological advancements, the importance of human factors in the maritime sector has been on the increase. Especially, seafarers in officer class play a significant role in the management of ships and fleets. Safe and quality ship management can be ensured with officers who have high levels of professional commitment. Research shows that professional commitment positively affects job satisfaction, motivation, well-being and organizational commitment. In the study, it was determined that generation Y seafarers had higher levels of professional commitment than expected.

\section{Recommendations for future studies}

Further studies can be conducted on the factors affecting Professional commitment and variables affected by Professional commitment. In studies carried out on seafarers, a variety of issues can be clarified such as commitment, motivation, individual well-being, communication, team management and leadership, which predict professional commitment or predicted by professional commitment. Thus, healthy career planning can be achieved. Management of human resources appropriately is directly related to correct career planning. Issues related to human factors are important for safety and quality management in the maritime sector. Research on the factors affecting the career development of new generations will enable individuals and institutions to make suitable career planning.

\section{Resources}

Albdour, A.A., Altarawneh, I.I., (2014). Employee Engagement and Organizational Commitment: Evidence from Jordan, International Journal of Business, 19 (2): 193-212.

Aslan, Ş. (2008). Investigation of the relationship between organizational citizenship behavior and commitment to organization and profession , Journal of Management and Economics, Celal Bayar University, Faculty of Economics and Administrative Sciences, 15 (2), 163-178.

Bagraim, J. J. (2003). “The Dimensionality of Professional Commitment”, Journal of Industrial Psychology, 29(2), 6-9.

Balay, R. (2000). Organizational Commitment in Manager and Teachers, Nobel Publication Distribution, Publication No: 206, Ankara. 
Baysal AC, Paksoy M. (1999). Meyer-Allen model in a multi-faceted study of commitment to the profession and organization. IU Faculty of Business Journal 1999; 28: 1-15.

Becker, T. E., Kernan, M. C., Clark, K. D., \& Klein, H. J. (2015). Dual commitments to organizations and professions: Different motivational pathways to productivity. Journal of Management. https:// doi.org/10.1177/0149206315602532

Benligiray, S. ve Sönmez, H. (2011). The Relationship Between Nursing Professional Commitment and Other Commitment Forms: Commitment to Organization, Commitment to Work and Family Commitment Hacettepe University School of Health Sciences Journal of Nursing, 18 (1): 28-40.

Blau, G. ve Lunz, M. (1998), “Testing the Incremental Effect of Professional Commitment on Intent to Leave One's Profession Beyond the Effects of External, Personal, and Work- related Variables", Journal of Vocational Behavior, 52, 260-269

Broadbridge, A. M.; Maxwell, Gillian A. \& Ogden, S.M. (2007). Experiences, perceptions and expectations of retail employment for generation Y, Career Development International, Volume 12, Number 6, p.523-544.

Carson, K. D. and Bedian, A.G. (1994). "Career Commitment: Construction of a Measure and Examination of Its Psychometric Properties”. Journal of Vocational Behavior, 44, 237-262.

Cohen, A. (2000). "The relationship between commitment forms and work outcomes: a comparison of three models", Human Relations, 53 (3), 387-417

Çakır Ö. (2001). Affecting factors of work commitment, Seçkin Publishing, Ankara.

Çam, S., (2009). Times of Y generation, Dünya Daily Economics News

http://www.dunyagazetesi.com.tr/haber.asp?id=61403\#

Çetinkaya A, Özmen D, Temel A.B., (2015). Investigation of Professional Commitment of the Newly Graduated Nurses. DEUHFED, 8(2), 54-60.

Dorenkamp, I and Ruhle, S. (2019). Work-Life Conflict, Professional Commitment, , and Job Satisfaction Among Academics, The Journal of Higher Education, 90:1, 56-84, DOI: $10.1080 / 00221546.2018 .1484644$

Dorenkamp, I., \& Weiß, E.-E. (2018). What makes them leave? A path model of postdocs' intentions to leave academia. Higher Education, 75, 747-767, doi:10.1007/s10734-017- 01647

Esencan, T.Y, \& Özdil H. (2017). Evaluation of Professional Commitment of Nurses in Generation X and Y, Ege University Journal of Faculty of Nursing Archive Volume 33, Issue 3

Goswami S., Mathew M.ve Chadha N.K. (2007), "Differences in Occupational Commitment amongst Scientists in Indian Defense, Academic, and Commercial R \& D Organizations", Vikalpa, 32(4), 13-27.

Gürbüz, S. (2015), Generation differences: Myth or Reality ?, Work and human magazine, April, 2 (1): 39-57

Hoff, T. J. (2000). Professional commitment among US physician executives in managed care. Social Science \& Medicine, 50(10), 1433-1444. https://doi.org/10.1016/S0277$\underline{\text { 9536(99)00410-4 }}$ 
Kuram E. (2018). Turkish Y generation what tells the company's ?, Harvard Business Review Turkey,https://hbrturkiye.com/dergi/turkiye-nin-y-kusagi-sirketlere-ne-soyluyor

IMO Sub-Committee on Flag State Implementation. (2008) Responsibilities of Governments and Measures to Encourage Flag State Compliance.

Ivtzan, I., Sorensen, E. ve Halonen, S. (2013), "The Effect of Occupational Meaningfulness on Occupational Commitment", International Journal of Psychological Research, 6(2), 15- 23

Lanchman R, Aranya N. (1986). Evaluation of alternative models of commitment and job attitudes of professionals. Journal of Occupational Behaviour 1986; 7: 227-243.

Lu K.Y., Chiou S.L., Chang Y.Y. (2000). A study of the professional commitment changes from nursing students to registered nurses. Kaohsiung J Med Sci, 16(1):39-46.

Lu, K.Y., Lin P.L., Wu, C.M., Hsieh, Y.L., Chang, Y.Y. (2002). The relationships among turnover intentions, professional commitment and job satisfaction of hospital nurses. J Prof Nurs, 18(4): 214-9.

Lub, X., M. N. Bijvank, P. M. Bal, R. Blomme, ve R. Schalk. (2012). “Different or Alike? Exploring the Psychological Contract and Commitment of Different Generations of Hospitality Workers.” International Journal of Contemporary Hospitality Management 24 (4): 553-573.

Meyer, J. P., Allen, N. J. and Smith, C. A. (1993), "Commitment to Organizations and Occupations: Extension and Test of a Three Component Conceptualization", Journal of Applied Psychology, 78(4), 538-551

Meyer, J. P., \& Herscovitch, L. (2001). Commitment in the workplace: Toward a general model. Human Resource Management Review, 11, 299-326. doi:10.1016/S1053-4822(00) 00053-X

Morrow, P. C.; (1983), "Concept Redundancy in Organizational Research: The Case of Work Commitment”, Academy of Management Review, 8, ss. 486-500.

Özaydin, S., (2019). Organizational culture as a tool for managing a multigenerational workforce in project management. Research Journal of Business and Management (RJBM), V.6(3), p.185-203

Solmuş, T. (2004) Emotions and Interpersonal Relations in Business Life, Beta Publications,Ístanbul ISBN:9789752953703

Sorensen, J.E. and Sorensen, T.L. (1974), “The Conflict of Professionals in Bureaucratic Organizations", Administrative Science Quarterly, 19, 98-106.

Şimşek, M. Ş. ve Aslan, Ş. (2012). "Mesleki ve örgütsel bağlılığın, örgütsel davranışa ilişkin sonuçlarla ilişkileri”, Selçuk Üniversitesi İİBF Sosyal ve Ekonomik Araştırmalar Dergisi, 23, 413-454.

Teng, C.I., Shyu, Y.I.L., Chang, H.Y. (2007). Moderating effects of professional commitment on hospital nurses in Taiwan. J Prof Nurs, 23(1):47-54

Tinaz, P. (2013). Case studies from business life, Beta Publications, Istanbul ISBN:6053778332 
Twenge, Jean M., Stacy M. Campbell, Brian J. Hoffman, and Charles E. Lance. 2010.

"Generational Differences in Work Values: Leisure and Extrinsic Values Increasing, Social and Intrinsic Values Decreasing." Journal of Management 36 (5): 1117-1142.

Zopiatis, A., Krambia-Kapardis M. And Varnavas A. (2012). Y-ers, X-ers and Boomers: Investigating the multigenerational (mis) perceptions in the hospitality workplace, Tourism and Hospitality Research12(2) 101-121, DOI: 10.1177/1467358412466668 